\title{
Komparasi Kinerja Instrumen Investasi Berbasis Syariah dengan Konvensional pada Pasar Modal di Indonesia
}

\author{
Muhammad Nizar, Moh.Mukhsinin Syu'aibi
}

Universitas Yudharta Pasuruan

muhammadnizar@yudharta.ac.id, mukhsinin.2000@gmail.com

\section{Article Info}

Article history:

Received Oct19th, 2020

Revised Oct 30th, 2020

Accepted Nov 5th, 2020

\section{Keyword:}

Performance Comparisons, Sharia Investment, Conventional Investments, Capital market.

\begin{abstract}
The main objective of investors in investing is to make a profit. This study compares the performance of the index and performance of mutual funds between sharia and conventional bases. The index comparison is made between the Jakarta Islamic Index (JII) as a sharia investment and the LQ45 index as a conventional investment. The observation period used is 2016 to 2018.

The results showed that the statistical descriptive table shows that the mean value of conventional mutual funds performance is 0.00 or $0 \%$, while the mean value of Islamic mutual funds performance is 0.00 or $0 \%$, it can be concluded that the mutual funds performance owned by conventional and Islamic companies are not has differences, which means that investing in mutual funds in two types of companies, both conventional and sharia, have equal risks and benefits.
\end{abstract}

Copyright@2020 Program Studi Ekonomi Syariah Universitas Yudharta Pasuruan All rights reserved.

DOI: https://doi.org/10.35891/ml.v12i1.2379

\section{Corresponding Author:}

Muhammad Nizar,

Lecturer in Sharia Economics, University of Yudharta Pasuruan

Email: muhammadnizar@yudharta.ac.id 


\section{A. Pendahuluan}

Investasi adalah kegiatan menyisihkan sebagian harta untuk ditempatkan pada sarana investasi dengan harapan dapat memetik nilai ekonomis di masa depan (Achsien, 2000). Pada hakekatnya, investor akan memilih untuk menginvestasikan hartanya dengan keputusan-keputusan finansialnya, yaitu mempertimbangkan (return) imbal hasil dan (risk) resiko (Tandelilin, 2010). Tjiptono \& Fachrudin (2012) menegaskan bahwa secara teoritis, terhadap investasi yang lebih beresiko, investor akan mengharapkan return yang lebih tinggi. Akan tetapi ada investor yang dalam aktifitasnya tidak semata mempertimbangkan aspek financial namun juga mempertimbangkan nilai- nilai yang dimilikinya, seperti ajaran agama.

Di Indonesia yang mayoritas penduduknya beragama Islam mulai dikembangkan investasi berbasis syariah, dimana investasi tersebut menintegrasikan nilai-nilai agama yang di yakini dalam kegiatan investasi dengan cara melakukan proses screening dalam memilih instrument investasinya (Achsien, 2000). Salah satu sarana dalam berinvestasi sesuai prinsip Islam adalah melalui pasar modal syariah.

PT Bursa Efek Indonesia meluncurkan Jakarta Islamic Index (JII) yang merupakan index dari saham yang paling likuid dan memenuhi criteria syariah sesuai ketentuan DSN (Dewan Syariah Nasional) (Fadilla, 2018; Hasibuan, 2018). Sedangkan Indeks Saham Syariah Indonesia yang menggambarkan kinerja seluruh salam syariah di Indonesia baru diaplikasikan pada tanggal 12 Mei 2011. Indonesia dinyatakan secara resmi memiliki Pasar Modal Syarah pada tanggal 14 Maret 2003, dengan saham yang diperdagangkan melalui proses screening sesuai dengan kriteria syariah (Hermawan, 2018; Soemitra, 2019).

Indeks yang paling dikenal oleh banyak investor adalah Indeks Likuid 45 (LQ45) dan Jakarta Islamic Indeks (JII), kedua indeks saham tersebut memiliki daftar yang aktif dan likuid dibandingkan daftar saham pada indeks lainnya. Indeks LQ45 dan JII adalah indeks yang diamati kinerjanya oleh investor karena dipercaya dapat memberikan return yang tinggi dan dianggap dapat memberikan return saham yang cukup tinggi dikarenakan saham-saham yang berada di Indeks tersebut merupakan saham-saham yang unggul.

Dukungan dari regulasi untuk mempercepat akselerasi industry keuangan syariah telah dilakukan seperti dengan disahkannya Undang-Undangan Surat Berharga Syariah Nasional (UU SBSN). Dan juga diterbitkannya Sukuk Negara pada tahun 2008 dengan underlying asset barang milik negara (Megasyara, 2014; Yahya, 2015). Dengan adanya akselerasi instrument syariah, membuka peluang bagi instrument Reksadana Syariah sebagai instrument portofolio investasi syariah untuk berkembang. Berdasarkan data statistic Bapepam LK desember 2011 sampai akhir tahun 2018 NAB Reksadana syariah mengalami peningkatan jumlah NAB sebesar Rp. 6,80\%, dari 220 Manajer Investasi, dengan jumlah produk 182 produk (Bachruddin, 2008). Demikian pula dengan saham, sampai dengan akhir tahun 2018 sudah mencapai 407 saham yang memenuhi kriteria syariah (OJK, 2018).

Instrumen syariah di Indonesia terus menunjukkan pertumbuhan, namun data bapepam menunjukkan bahwa sebaran market share industry keuangan syariah dalam

$2 \mid$ Komparasi Kinerja Instrumen Investasi Berbasis Syariah dengan Konvensional ... 
kurun waktu terakhir masih dalam kisaran 5,70\% dariindustry keuangan nasinal (OJK, 2018). Nurhayati, (2017) mengungkapkan bahwa salah satu cara untuk meningkatkan market share instrument investasi berbasis syariah adalah dengan menjaga return syariah ke tingkat yang dapat diterima pasar. Keunggulan prinsip ekonomi syariah yang menekankan pada prinsip keadilan, pelarangan spekulasi, pelarangan riba seharusnya berimbas pula pada return yang dihasilkan (Budiono, 2017)

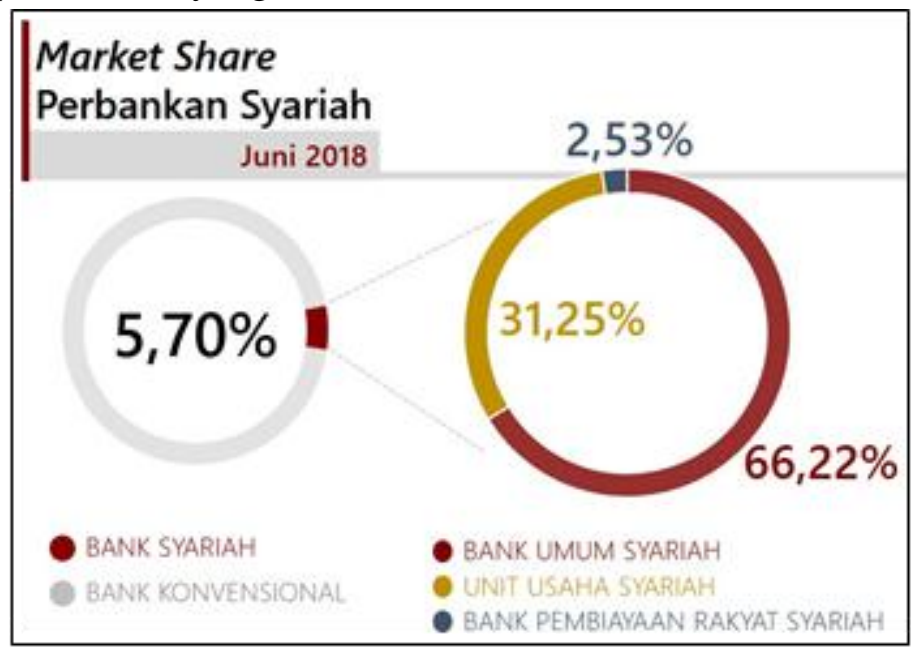

Gambar 1: Market Share Perbankan Syariah Juni 2018

Dari data statistik Bapepam mengenai indeks perkembangan pasar modal Indonesia, diungkapkan selama tahun 2016 saham-saham syariah memberikan keuntungan lebih rendah dibandingkan saham-saham lainnya. Dimana berdasarkan perhitungan Indeks saham JII memberikan return 12\%, sedangkan LQ 45=13\% (Dian Anggraini \& Pratomo, 2018).

Berdasarkan penelitian Lailiyah et al., (2016), bahwa perbandingan rata-rata kinerja Reksadana konvensional dengan Reksadana syariah pada jangka panjang menunjukkan bahwa rata-rata kinerja ketiga indeks, terhadap kedua Reksada na tersebut tidak berbeda secara signifikan. Sedangkan penelitian Putra (2019) dengan menggunakan priode jangka pendek menunjukkan bahwa rata-rata return indeks JII tidak berbeda secara signifikan dengan kisaran indeks LQ-45. Penelitian ini ingin fokus meneliti perbandingan kinerja investasi syariah dengan investasi konvensional pada jangka menengah 3 tahun sebagai priode investasi yang moderat.

Penelitian ini memiliki rumusan apakah terdapat perbedaan yang signifikan antara kinerja indeks saham-saham syariah dengan kinerja indeks saham-saham konvensional, apakah terdapat perbedaan yang signifikan antara kinerja Reksadana syariah dengan kinerja Reksadana konvensional. Tujuan penelitian ini diantaranya: Mengembangkan model mengembangkan konsep atau teori tentang pasar modal khususnya yang berkaitan dengan investasi, reksadana, pasar modal. Penelitian ini penting dilakukan karena memiliki kontribusi dalam pengembangan penelitian bidang ekonomi yang berbasis pasar modal, memiliki kontribusi untuk program studi, penelitian ini dijadikan rujukan dan pedoman matakuliah pasar modal, lembaga keuangan syariah. 


\section{B. Kajian Teori}

\section{Investasi}

Hutajulu (2015) mendefinisikan bahwa investasi adalah pengaitan sumber-sumber dalam jangka panjang untuk menghasilkan laba dimasa yang akan dating. Investasi dapat pula didefinisikan sebagai penempatan sejumlah dana pada saat ini dengan harapan untuk memperoleh keuntungan di masa mendatang (Halim, 2005). Menurut Halim (2005) umumnya investasi dapat dibedakan menjadi dua, yaitu investasi pada financial assets dan investasi pada real asset.

\section{Pasar Modal}

Pasar modal dalam arti sempit adalah suatu tempat dalam pengertian fisik yang terorganisasi tempat efek-efek di perdagangkan yang disebut bursa efek. Pengertian bursa efek (stock exchange) adalah suatu sistem yang terorganisasi yang mempertemukan penjual dan pembeli efek yang dilakukan baik secara langsung maupun tidak langsung (Hartono, 2017). Menurut Undang-Undang Pasar Modal No. 8 tahun 1995 tentang Pasar Modal mendefinisikan pasar modal "sebagai kegiatan yang bersangkutan dengan Penawaran umum dan perdagangan Efek, Perusahaan Publik yang berkaitan dengan Efek yang diterbitkannya, serta lembaga dan profesi yang berkaitan dengan Efek" (Sholihin, 2013).

\section{Reksadana}

Menurut Putra \& Mawardi, (2016), secara umum pengertian reksadana adalah suatu kumpulan dana dari masyarakat, pihak pemodal atau pihak investor untuk kemudian dikelola oleh manajer investasi dan diinvestasikan pada berbagai jenis portofolio investasi efek atau produk keuangan lainnya. Soemitra (2019) membagi reksa dana menjadi beberapa jenis berdasarkan portofolio investasinya yaitu: Reksa Dana Pasar Uang, Reksa Dana, Reksa Dana Saham, Reksa Dana Campuran.

Fauzia (2011) dalam mengelola reksadana manajer investasi bekerjasama dengan bank kustodian. Bank Kustodian adalah perusahaan yang kegiatan usahanya melakukan penyelesaian transaksi reksadana, melakukan penyimpanan, penjagaan dan pengadministrasian kekayaan reksadana. Reksadana merupakan hubungan trilateral antara pemegang unit penyertaan, manajer investasi dan kustodian (trustee), yang terikat oleh sebuah kontrak atau trust deed secara legal. Kontrak ini terdaftar di Bapepam. Dalam reksadana uang yang terkumpul dari investor kan digunakan oleh manajer investasi untuk membeli surat-surat berharga. Adapun keuntungan atau kerugian investasi dalam reksadana dapat dilhat dari Nilai Aktiva Bersih (NAB) yang juga digunakan sebagai dasar pembelian dan penjualan unit penyertaan (Nizar, 2018; Nuhyatia, 2013).

Dalam penelitian ini data mengenai kinerja reksadana akan diperoleh melalui PT indopremier. PT Indo Premier Sekuritas (“IndoPremier") adalah perusahaan penyedia jasa keuangan terintegrasi di bidang pasar modal yang melayani klien individu maupun korporasi berdasarkan ijin Badan Pengawas Pasar Modal/Otoritas Jasa Keuangan (OJK) nomor KEP-11/PM/PPE/1996. Pada tahun 2002, founders dari IndoPremier membeli perusahaan efek ini dan dinamakan PT Indo Premier Securities yang kemudian berubah menjadi PT Indo Premier Sekuritas pada tahun 2017. Sejak itu, IndoPremier menjadi

4 | Komparasi Kinerja Instrumen Investasi Berbasis Syariah dengan Konvensional ... 
pelopor dalam berbagai bidang usaha efek di Indonesia. Hingga saat ini, dari sisi pangsa pasar maupun kapitalisasi modal, IndoPremier telah tumbuh dan berkembang menjadi salah satu pelaku pasar modal terbesar dengan kapitalisasi modal yang lebih dari Rp 1.5 Triliun per 31 Desember 2019.

Penelitian ini dilakukan salah satunya pada Indopremier dikarenakan, PT Indopremier memiliki kinerja yang unggul yakni dalam bidang usahanya, IndoPremier bergerak di bidang perantara pedagang efek, penjamin emisi efek, dan manajemen investasi. Nasabah-nasabah yang terkait, dapat dibagi menjadi 2 kategori yang berbeda yaitu Retail dan Institusi. Hingga saat ini, IndoPremier adalah salah satu perusahaan efek yang mempunyai peran sangat besar di 2 kategori ini. Hanya ada beberapa perusahaan efek di Indonesia yang sangat berhasil di kedua kategori nasabah, karena biasanya suatu perusahaan efek hanya dapat berkonsentrasi di satu kategori nasabah.

\section{Metode}

Penelitian ini melakukan perbandingan kinerja indeks dan kinerja sersadana antara basis syariah dengan basis konvensional. Perbandingan indeks dilakukan antara Jakarta Islamic Indeks (JII) sebagai proxy investasi syariah dengan indeks LQ45 sebagai proxy investasi konvensional. Periode pengamatan yang digunakan adalah tahun 2016 sampai dengan 2018. Penelitian ini dilakukan di Jakarta Islamic Indeks (JII) yang bertempat di Pojok BEI Universitas Brawijaya.

\section{Definisi Operasional Variabel}

\section{a. Kinerja Saham}

Kinerja saham adalah ukuran pengembalian saham selama periode waktu tertentu. terdapat sejumlah ukuran kinerja saham dan masing-masing mencakup karakteristik dan manfaatnya sendiri selama pada analisis return (Alexander \& Buchholz, 1978). Adapun alat ukur yang digunakan untuk mengukur kinerja saham adalah return saham. Return saham merupakan tingkat keuntungan yang dinikmati oleh pemodal atas suatu investasi saham yang dilakukan oleh pemodal (Latifah, et. al., 2017).

Perbandingan indeks dilakukan dengan membandingkan return bulanan dari masing-masing indeks, untuk kemudian dilakukan pengujian dengan menggunakan uji-t antara JII dengan LQ-45. Dengan demikian dapat diketahui apakan terdapat perbedaan yang signifikan antara rata-rata return bulanan JII dengan rata-rata return bulanan LQ-45. Return bulanan dari masing-masing indeks diperoleh dari persamaan (Halim, 2005):

\section{Return bulanan $=\underline{\text { indeks } \mathrm{t}-\text { indeks }}$ \\ $\underline{t-1}$}

Keterangan

Indeks $\mathrm{t} \quad$ : indeks pada bulan ke- $\mathrm{t}$

Indeks t-1 : indeks pada bulan sebelumnya 


\section{b. Kinerja Reksadana}

Kinerja perbandingan Reksadana dilakukan terhadap satu wakil Reksadana syariah dan satu wakil Reksadana konvensional, dan untuk menghindari bisa karena perbedaan kemampuan pengelolaan dari manajer investasi, maka digunakan Reksadana syariah dan Reksadana campuran (konvensional) yang dilakukan oleh manajer investasi yang sama, yaitu PT Indopremier. Kinerja Reksadana diukur dengan model Sharpe. Menurut Sharpe, kinerja Reksadana dapat diprediksi dengan menggunakan dua ukuran, yaitu: expected rate of return (ER) yaitu return rata-rata dan predicted variability of risk yang diekspresikan sebagai deviasi standart return. Reksadana layak dibeli jika memiliki excess return (Rp-Rf) yang bernilai positif. Berikut rumus indeks sharpe (Setiarsih, 2019):

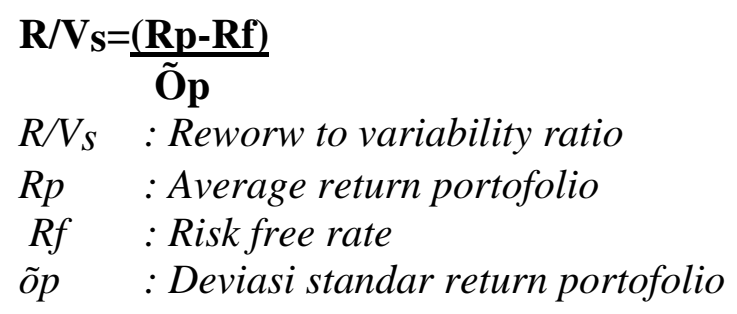

Selanjutnya Kinerja Reksadana Syariah dan Reksadana Umum /konvensional diukur menggunakan Hi-Lo Performance, dimana menurut IPOTFORUM, Hi-Lo Performance menentukan grafik NAV (Net Asset Value) dalam suatu periode baik itu tiga bulan, enam bulan, sembilan bulan, 1 tahun, 2 tahun maupun 3 tahun. Nilai aktiva bersih pada penutupan terakhir berada pada beberapa persen dari titik terendah suatu reksadana dalam 1 periode. Sehingga semakin tinggi nilai Hi-Lo akan semakin bagus. Adapun rumus perhitungan Hi-Lo Performance adalah sebagai berikut :

\section{Hi Lo $=\underline{\text { Last NAV }- \text { Low NAV }}$ High NAV - Low NAV}

Kinerja Reksadana selanjutnya juga di ukur menggunakan metode DrawDown, metode Draw-Down menggambarkan suatu nilai asset bersih yang turun kebawah, terdalam/tercuram dalam suatu periode yang ditentukan. Apabila nilainya 0,10 berarti tingkat penurunannya pada periode tertentu tersebut $10 \%$ dari nilai investasi awal. Sehingga dapat disimpulkan bahwa rasio Draw-Down merupakan alat analisis yang digunakan untuk melihat tingkat kerugian maksimal produk reksadana, semakin kecil presentase draw-down suatu reksadana maka akan semakin bagus. Hal tersebut berarti bahwa masa penurunan yang dialami investor pemegang reksadana memiliki periode sebentar atau cepat pulih dari masa penurunannya (IndoPremier, 2018). 
..:: Malia: Jurnal Ekonomi Islam Vol. 12 No. 1, Desember 2020 ::..

\begin{tabular}{|c|c|c|c|}
\hline No & Variabel & Alat Ukur & Referensi \\
\hline \multirow[t]{2}{*}{1.} & \multirow[t]{2}{*}{ Kinerja Saham } & Return Bulanan: & \multirow[t]{2}{*}{ (Halim, 2005) } \\
\hline & & Return bulanan $=\frac{\text { indeks } \mathrm{t}-\text { indeks } \mathrm{t}-1}{\text { Indeks t-1 }}$ & \\
\hline \multirow[t]{4}{*}{2.} & \multirow{4}{*}{$\begin{array}{l}\text { Kinerja } \\
\text { Reksadana }\end{array}$} & Indeks Sharpe: & \multirow{2}{*}{$\begin{array}{l}\text { (Setiarsih, } \\
\text { 2019) }\end{array}$} \\
\hline & & $\begin{array}{ll}\mathbf{R} / \mathbf{V}_{\mathrm{s}}= & \frac{(\mathbf{R p}-\mathbf{R f})}{\tilde{\mathbf{O}} \mathbf{p}} \\
R / V_{s} & : \text { Reworw to variability ratio } \\
R p & : \text { Average return portofolio } \\
R f & : \text { Risk free rate } \\
\tilde{O} p & : \text { Deviasi standar return portofolio }\end{array}$ & \\
\hline & & $\begin{array}{l}\text { Hi-Lo Performance } \\
\text { Hi Lo }=\frac{\text { Last NAV - Low NAV }}{\text { High NAV - Low NAV }}\end{array}$ & $\begin{array}{l}\text { (IndoPremier, } \\
\text { 2018) }\end{array}$ \\
\hline & & Draw-Down analysis & $\begin{array}{l}\text { (IndoPremier, } \\
\text { 2018) }\end{array}$ \\
\hline
\end{tabular}

Sumber: Data Diolah Peneliti 2020

\section{Analisis Data}

Penelitian inI berfokus pada analisis perbandingan dua jenis kinerja investasi, yakni kinerja saham dan kinerja reksadana. Adapun perusahaan yang dinilain kinerja sahamnya dalam penelitian ini adalah perusahaan yang terindeks JII dan indeks LQ45 yang diperoleh dari bursa efek Indonesia (BEI). Sedangkan analisis perbandingan kinerja reksadana dalam penelitian adalah dengan menganalisis perusahaan pada IPOTGO atau Indopremier.com. Metode pengumpulan data empiris dan keteranganketerangan yang berkaitan dengan permasalahan tersebut, dilakukan melalui studi kepustakaan dan konsultasi dengan PT Indopremier. Data-data yang akan dianalisis menggunakan data sekunder berupa laporan publikasi PT BEI dan PT Indopremier pada priode 2015 sampai dengan 2018. Untuk pengujian hipotesis dari data-data tersebut digunakan metode uji beda rata-rata ( $\mathrm{t}$ test) dengan menggunakan softwere SPSS (Farid Harianto \& Siswanto Sudomo, 1998)

Prosedur uji paired sample t-test (Astikawati \& Sore, 2019):

a. Menentukan hipotesis; yaitu sebagai berikut:

Ho1: tidak terdapat perbedaan antara kinerja indeks saham-saham syariah dengan kinerja indeks saham-saham konvensional.

Ho2: terdapat perbedaan antara kinerja indeks saham-saham syariah dengan kinerja indeks saham- saham konvensional.

Ha1 : Tidak terdapat perbedaan yang signifikan antara kinerja reksadana syariah dengan kinerja reksadana konvensional.

Ha2: Terdapat perbedaan yang signifikan antara kinerja reksadana syariah dengan kinerja reksadana konvensional. 
b. Analisis Deskriptif

c. Menentukan level of significant sebesar 5\% atau 0,05/ Menentukan kriteria pengujian Ho ditolak jika nilai probabilitas $<0,05$, berarti terdapat perbedaan kinerja indeks saham-saham syariah dengan kinerja indeks saham-saham konvensional. Ho diterima jika nilai probabilitas $>0,05$, berarti tidak terdapat perbedaan antara kinerja indeks saham-saham syariah dengan kinerja indeks saham-saham konvensional).

d. Penarikan kesimpulan berdasarkan pengujian hipotesis.

\section{Hasil dan Pembahasan}

\section{Gambaran Umum Objek Penelitian}

Perusahaan yang menjadi objek dalam penelitian ini yang akan di nilai kinerja sahamnya yakni perusahaan yang masuk dalam indeks LQ45 serta indeks JII selama periode tahun 2015-2018. Adapun Jumlah perusahaan total dalam penelitian ini, akan di jelaskan pada Tabel Berikut:

Tabel 1 Objek Penelitian 1

\begin{tabular}{|c|c|c|}
\hline \multirow{2}{*}{ Tahun } & \multicolumn{2}{|c|}{ Indeks Kinerja Saham } \\
\cline { 2 - 3 } & LQ45 & JII \\
\hline 2015 & 45 & 30 \\
\hline 2016 & 45 & 30 \\
\hline 2017 & 45 & 30 \\
\hline 2018 & 45 & 30 \\
\hline Jumlah Populasi Penelitian & 180 & 120 \\
\hline
\end{tabular}

Sumber: www.idx.co.id; 2015-2018

Adapun perusahaan yang menjadi objek dalam penelitian ini yang akan di nilai kinerja Reksadananya yakni perusahaan yang Tergabung pada PT IndoPremier pada periode 2019-2020. Adapun Jumlah perusahaan total dalam penelitian ini, antaralain 43 perusahaan syariah dan 187 perusahaan konvensional. Adapun data terkait Reksadana di dapat melaui aplikasi Ipot Go milik perusahaan indopremier Securities (Ipotgo, 2020). Penelitian ini menggunakan analisis statistik menggunakan aplikasi SPSS 20,0.

\section{Analisis Deskriptif Statistik}

Analisis deskriptif pada penelitian ini akan ditunjukkan pada tabel berikut:

Tabel Deskriptif Statistik

\begin{tabular}{|l|r|r|r|r|c|}
\hline & $\mathrm{N}$ & Minimum & Maximum & Mean & $\begin{array}{c}\text { Std. } \\
\text { Deviation }\end{array}$ \\
\hline Return Saham LQ45 & 180 & -.9276 & 9.4812 & .214951 & 1.0796133 \\
\hline Return Saham JII & 120 & -.9276 & 10.2273 & .219091 & 1.2630857 \\
\hline
\end{tabular}


..:: Malia: Jurnal Ekonomi Islam Vol. 12 No. 1, Desember 2020 ::..

\begin{tabular}{|l|r|r|r|r|r|}
\hline $\begin{array}{l}\text { Kinerja Reksadana } \\
\text { Konvensional }\end{array}$ & 187 & -3.4977 & 1.3836 & .000000 & 1.0000000 \\
\hline Kinerja Reksadana Syariah & 43 & -1.3730 & 2.2653 & .000000 & 1.0000000 \\
\hline
\end{tabular}

Sumber:Data Diolah Peneliti, 2020

Tabel deskriptif statistik menunjukkan bahwa nilai mean return bulanan saham LQ45 adalah 0,214951 atau sebesar 21,4\% sedangkan nilai mean dari return saham bulanan perusahaan yang terindeks pada JII sebesar 0.21901 atau sebesar $21,9 \%$ hal ini dapat disimpulkan bahwa kinerja saham yang dimiliki oleh perusahaan yang terindeks LQ45 dan JII memiliki perbedaan yang sangat kecil sekali yakni sebesar 0,5\% dimana perusahaan yang memiliki rata-rata kinerja saham terbaik adalah perusahaan yang terindeks JII.

Tabel deskriptif statistik menunjukkan bahwa nilai mean kinerja reksadana konvensional adalah 0,00 atau sebesar $0 \%$ sedangkan nilai mean dari kinerja reksadana syariah sebesar 0.00 atau sebesar $0 \%$ hal ini dapat disimpulkan bahwa kinerja reksadana yang dimiliki oleh perusahaan konvensional dan syariah tidak memiliki perbedaan, yang berarti bahwa melakukan investasi reksadana pada dua jenis perusahaan baik itu konvensional maupun syariah sama-sama memiliki resiko dan manfaat yang seimbang (Bakhri, 2018; Santosa \& Huda, 2020; Syafrida et al., 2015).

Apabila dilihat lebih lanjut pada nilai minimum dan maksimum kedua jenis perusahaan ditemukan nilai kinerja terburuk pada perusahaan reksadana konvensional sebesar -3.4977 dan nilai kinerja tertinggi sebesar 1.3836 sedangkan pada perusahaan reksadana konvensional nilai kinerja terburuk lebih kecil dari perusahaan konvensional yakni sebesar -1.3730 dan nilai kinerja terbaik sebesar 2.2653 nilai minimum dan maksimum ini tidak dapat digunakan sebagai patokan untuk mencari perusahaan reksadana mana yang terbaik karena dalam masing-masing keseluruhan nilai kinerja reksadana terdapat perbedaan. Contohnya adalah perusahaan reksadana syariah sekilas tampak memiliki kinerja reksadana terburuk dengan nilai lebih rendah dari kinerja reksadana konvensional yakni -1.3730 namun pada kenyataannya terdapat banyak perusahaan yang memiliki kinerja reksadana minus sehingga menghasilkan nilai mean yang sama-sama 0,00 . Hal ini dapat disimpulkan bahwa tidak terdapat perbedaan antara rata-rata/ mean kinerja reksadana perusahaan konvensional dan perusahaan syariah.

Masih sedikit orang mengetahui dan berinvestasi langsung di reksadana, namun seseorang hanya mengetahui saja. Padahal tujuan reksa dana yaitu untuk mendapatkan hasil investasi atau return yang menguntungkan (Abdul Hamid \& Cahyadi, 2020; Sri Sandhi et al., 2017). Dalam pencapaian tujuan tersebut, reksa dana tidak terlepas dari pengaruh kinerja dalam pelaksanaan kegiatannya untuk mencapai return yang tinggi. Return dari reksa dana dikenal dengan nama nilai aktiva bersih (NAB) yang merupakan kunci untuk menilai kinerja reksa dana. Sharpe Ratio yang dikemukakan oleh Budi Setiawan (2017) dipergunakan untuk menilai kinerja reksa dana dengan memakai Nilai Aktiva Bersih.

Cara mempromosikan reksadana menurut Syaifullah et al., (2019), melalui 
edukasi ke perguruan tinggi, karena perguruan tinggi sebagai gerbang awal bagaimana masyarakat dapat berinvestasi, untuk melakukan investasi di sektor syariah dan konvenpun kalo tidak mengetaui caranya juga sulit (Pajar \& Pustikaningsih, 2017; Tandelilin, 2010). Dengan adanya promosi ke tingkat perguruan tinggi maka pasar modal akan berkembang. Disamping itu promosi offline dan online juga harus di galakkan, khususnya perusahaan securitasnya.

\section{Uji Hipotesis dan Pembahasan}

Adapun uji hipotesis pada penelitian ini dijelaskan pada tabel berikut:

Ho1 : Tidak terdapat perbedaan antara kinerja indeks saham-saham syariah dengan kinerja indeks saham-saham konvensional.

Ha1 : Terdapat perbedaan antara kinerja indeks saham-saham syariah dengan kinerja indeks saham-saham konvensional.

Tabel Uji Hipotesis 1

\begin{tabular}{|c|c|c|c|c|c|c|c|c|c|c|}
\hline & \multicolumn{2}{|c|}{$\begin{array}{c}\text { Levene's } \\
\text { Test for } \\
\text { Equality } \\
\text { of } \\
\text { Variances }\end{array}$} & \multicolumn{7}{|c|}{ t-test for Equality of Means } \\
\hline & & \multirow[t]{2}{*}{$\mathbf{F}$} & \multirow[t]{2}{*}{ Sig. } & \multirow[t]{2}{*}{$\mathbf{t}$} & \multirow[t]{2}{*}{ df } & \multirow[t]{2}{*}{$\begin{array}{l}\text { Sig. (2- } \\
\text { tailed) }\end{array}$} & \multirow[t]{2}{*}{$\begin{array}{c}\text { Mean } \\
\text { Difference }\end{array}$} & \multirow[t]{2}{*}{$\begin{array}{l}\text { Std. Error } \\
\text { Difference }\end{array}$} & \multicolumn{2}{|c|}{$\begin{array}{l}95 \% \text { Confidence } \\
\text { Interval of the } \\
\text { Difference }\end{array}$} \\
\hline & & & & & & & & & Lower & Upper \\
\hline ReturnSHM1_2 & $\begin{array}{l}\text { Equal } \\
\text { variances } \\
\text { assumed } \\
\text { Equal } \\
\text { variances } \\
\text { not } \\
\text { assumed }\end{array}$ & .086 & .769 & $\begin{array}{r}.037 \\
- \\
.036\end{array}$ & 364.376 & .971 & -.0041395 & .1126531 & $\begin{array}{l}-.2255559 \\
-.2305032\end{array}$ & .2172769 \\
\hline
\end{tabular}

Sumber: Data Diolah, 2020

Berdasarkan output di atas, diketahui nilai Sig. Levene's Test for Equality of Variances adalah sebesar 0,769>0,005 maka dapat diartikan bahwa varians data antara kinerja saham perusahaan terindeks LQ45 dengan perusahaan terindeks JII adalah homogen atau sama (Sujarweni, 2014; Deny, 2008). Analisis selanjutnya adalah nilai Sig. (2-tailed) yang menunjukkan keputusan hipotesis diterima atau ditolak, dalam tabel Sig. (2-tailed) ditemukan nilai sebesar 0,971>0,05 maka sebagaimana dasar pengambilan keputusan dalam uji independen sample t test dapat disimpulkan bahwa H01 diterima dan Ha1 ditolak.

Hal ini dikarenakan perbedaan kinerja saham antara perusahaan yang terindeks dalam LQ45 dan JII tidak memiliki nilai yang signifikan, yakni hanya memiliki perbedaan mean sebesar 0,05 atau 0,5\%. Perbedaan yang sangat kecil ini atau tidak adanya perbedaan yang siginifikan antara kinerja saham perusahaan yang terindeks 
LQ45 dan JII dikarenakan 99\% anggota perusahaan yanga ada pada indeks JII juga merupakan perusahaan yang terindeks pada LQ45 sehingga memiliki nilai kinerja saham yang sama, sedangkan $1 \%$ perusahaan yang terdapat dalam indeks JII adalah perusahaan yang tidak termasuk dalam indeks LQ45.

Hasil penelitian ini sejalan dengan penelitian yang dilakukan oleh (Syafrida et al., 2014) yang menemukan bahwa tidak terdapat perbedaan kinerja saham yang signifikan antara perusahaan berbasis konvensional dan syariah walau pada rata-rata returnya perusahaan syariah memiliki kinerja yang lebih baik. Hasil yang sama juga ditemukan pada penelitian (Amalia \& Kartikasari, 2016; Solikah, Mardani, 2017) yang menemukan bahwa perusahaan manufaktur terindeks syariah memiliki resiko investasi saham yang lebih kecil dan dapat dikatakan lebih menjamin keamanan investasi walau dengan return yang tidak terlalu besar.

Sedangkan uji hipotesis mengenai kinerja reksadana perusahaan konvensional dan perusahaan syariah dalah sebagai berikut:

Ho2 : Tidak terdapat perbedaan yang signifikan antara kinerja reksadana syariah dengan kinerja reksadana konvensional.

Ha2 : Terdapat perbedaan yang signifikan antara kinerja reksadana syariah dengan kinerja reksadana konvensional.

Tabel Uji Hipotesis 2

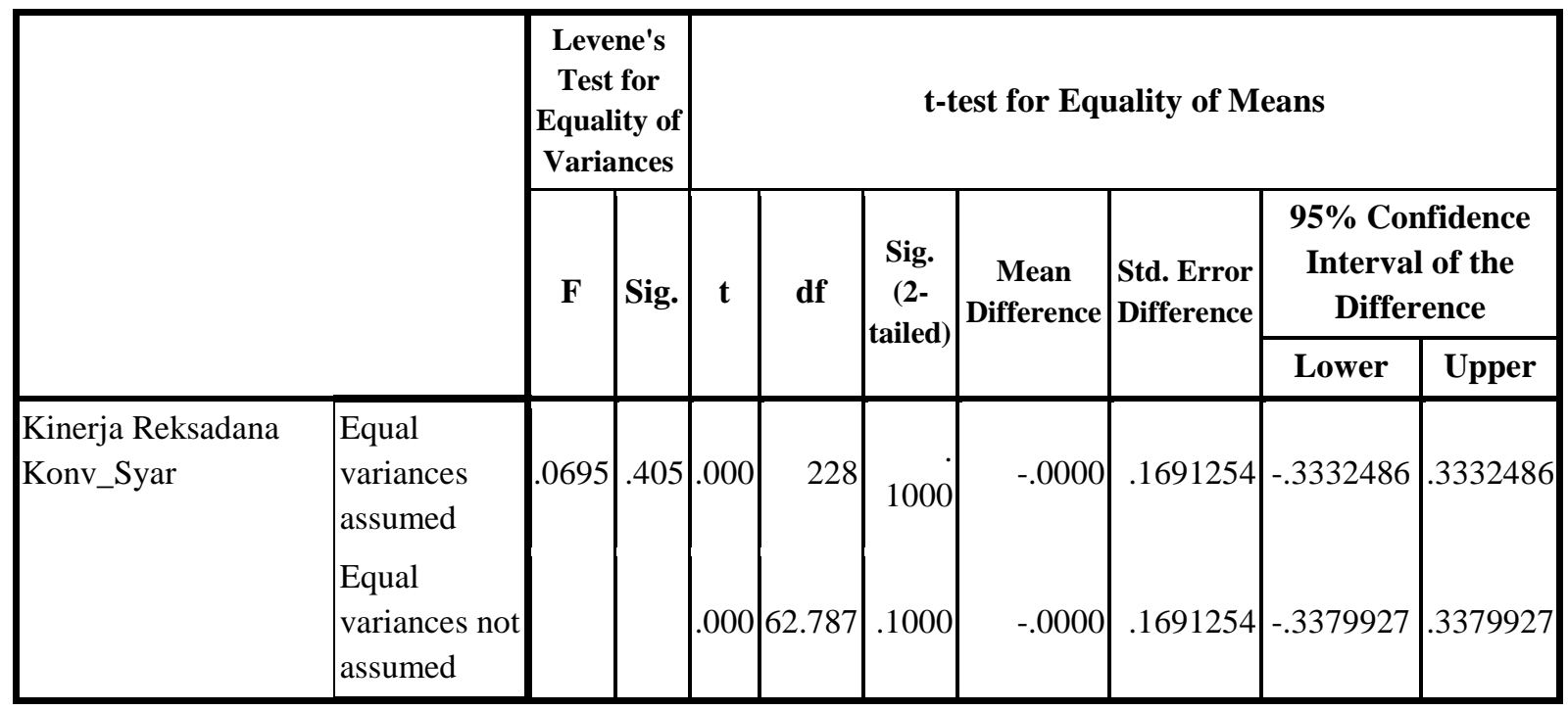

Sumber: Data Diolah, 2020

Berdasarkan output diatas, diketahui nilai Sig. Levene's Test for Equality of Variances adalah sebesar 0,405>0,005 maka dapat diartikan bahwa varians data antara kinerja saham perusahaan terindeks LQ45 dengan perusahaan terindeks JII adalah homogen atau sama (Dian Anggraini \& Pratomo, 2018; Prasetyo, 2018). Analisis selanjutnya adalah nilai Sig. (2-tailed) yang menunjukkan keputusan hipotesis diterima atau ditolak, dalam tabel Sig. (2-tailed) ditemukan nilai sebesar $1>0,05$ maka sebagaimana dasar pengambilan keputusan dalam uji independen sample $t$ test dapat disimpulkan bahwa $\mathrm{H} 02$ diterima dan $\mathrm{Ha} 2$ ditolak. 
Hal ini dikarenakan perbedaan kinerja saham antara perusahaan yang terindeks dalam LQ45 dan JII tidak memiliki nilai perbedaan. Hal ini dapat disimpulkan bahwa baik melakukan investasi reksadana dalam perusahaan konvensional dan perusahaan syariah memiliki taraf kualitas yang sama, yakni memiliki masing-masing resiko dan manfaat yang sama hal ini sesuai dengan penellitian yang dilakukan oleh (Hamzah \& Yohanes, 2014; Lestari, 2020; Ratnawati \& Khairani, 2013) yang menemukan bahwa tidak terdapat perbedaan antara kinerja reksadana syariah dengan reksadana konvensional.

\section{E. Kesimpulan}

Tabel deskriptif statistik menunjukkan bahwa nilai mean kinerja reksadana konvensional adalah 0,00 atau sebesar $0 \%$ sedangkan nilai mean dari kinerja reksadana syariah sebesar 0.00 atau sebesar $0 \%$ hal ini dapat disimpulkan bahwa kinerja reksadana yang dimiliki oleh perusahaan konvensional dan syariah tidak memiliki perbedaan, yang berarti bahwa melakukan investasi reksadana pada dua jenis perusahaan baik itu konvensional maupun syariah sama-sama memiliki resiko dan manfaat yang seimbang, Apabila dilihat lebih lanjut pada nilai minimum dan maksimum kedua jenis perusahaan ditemukan nilai kinerja terburuk pada perusahaan reksadana konvensional sebesar 3.4977 dan nilai kinerja tertinggi sebesar 1.3836 sedangkan pada perusahaan reksadana konvensional nilai kinerja terburuk lebih kecil dari perusahaan konvensional yakni sebesar -1.3730 dan nilai kinerja terbaik sebesar 2.2653 nilai minimum dan maksimum ini tidak dapat digunakan sebagai patokan untuk mencari perusahaan reksadana mana yang terbaik karena dalam masing-masing keseluruhan nilai kinerja reksadana terdapat perbedaan. 


\section{DAFTAR PUSTAKA}

Abdul Hamid, A. K., \& Cahyadi, I. F. (2020). Analisis Kinerja Reksadana Saham Syariah Di Pasar Modal Indonesia Menggunakan Metode Sharpe, Treynor, Dan Jensen Periode 2017-2018. MALIA: Journal of Islamic Banking and Finance, 3(2), 95.

Achsien, I. H. (2000). Investasi syariah di pasar modal: menggagas konsep dan praktek manajemen portfolio syariah. Gramedia Pustaka Utama.

Alexander, G. J., \& Buchholz, R. A. (1978). Corporate Social Responsibility and Stock Market Performance. Academy of Management Journal, 21(3), 479-486.

Amalia, A. D., \& Kartikasari, D. (2016). Analisis Perbandingan Kinerja Saham Perusahaan Manufaktur Terindeks Syariah dan Konvensional. Jurnal Akuntansi, Ekonomi Dan Manajemen Bisnis, 4(2), 128-135.

Astikawati, Y., \& Sore, A. D. (2019). PENGARUH VOLUME PERDAGANGAN SAHAM DI MATURE MARKET TERHADAP VOLUME PERDAGANGAN SAHAM DI EMERGING MARKET. JURKAMI : Jurnal Pendidikan Ekonomi, 4(1), 11-19.

Bachruddin, B. (2008). Keberadaan Obligasi Syari'ah di Indonesia: Peluang dan Tantangannya. Unisia, 31(70), 315-321.

Bakhri, S. (2018). Minat Mahasiswa Dalam Investasi Di Pasar Modal. Al-Amwal: Jurnal Ekonomi Dan Perbankan Syari'ah, 10(1), 146.

Budi Setiawan. (2017). Perbandingan Kinerja Pasar Modal Syariah Dan Konvensional : Suatu Kajian Empiris Pada Pasar Modal Indonesia. Jurnal Ilmiah Ekonomi Global Masa Kini, VOLUME 8 N(April).

Dian Anggraini, E. A., \& Pratomo, A. S. (2018). DETERMINAN RETURN SAHAM: JAKARTA ISLAMIC INDEX VS LQ 45. El Dinar, 6(2), 128.

Fadilla, F. (2018). Pasar Modal Syariah dan Konvensional. Islamic Banking: Jurnal Pemikiran Dan Pengembangan Perbankan Syariah, 3(2), 45-56.

Farid Harianto, \& Siswanto Sudomo. (1998). Perangkan dan Teknik Investasi di Pasar Modal Indonesia. PT Bursa Efek Jakarta.

Fauzia, I. Y. (2011). Pasar Modal Syariah di Indonesia. El-Qist, 1(1), 105-120.

Halim, A. (2005). Analisis investasi. Jakarta: Salemba Empat.

Hamzah, A., \& Yohanes, A. (2014). Analisis Perbandingan Kinerja Reksa Dana Syariah dengan Reksa Dana Konvensional Jenis Saham pada periode 2008 - 2012. MIX Jurnal Ilmu Manajemen, 39(1), 1-24. 
Hanina Maya Solikah , Ronny Malavia Mardani, B. W. (2017). Analisis Faktor-Faktor Yang Mempengaruhi Struktur Modal Dan Pengaruh Struktur Modal Terhadap Return Saham. Analisis Perbandingan Kinerja Keuangan Bank Umum Syariah Dengan Bank Umum Konvensional Di Indonesia (Studi Empiris Pada Perusahaan Perbankan Di Bursa Efek Indonesia), 07(17), 64-77.

Hartono, J. (2017). Teori portofolio dan analisis investasi (edisi Kesebelas). In Yogyakarta: $B P F E$.

Hasibuan, S. R. (2018). Minat Investasi Mahasiswa Untuk Berinvestasi di Pasar Modal Syariah (Studi Kasus di Galeri Investasi Syariah UIN Sumatera Utara Periode 20172018). Skripsi Universitas Islam Negeri Sumatera Utara Medan.

Hermawan, D. (2018). LEMBAGA KEUANGAN SYARIAH DI MATA TOKOH AGAMA NON MUSLIM. Rausyan Fikr : Jurnal Pemikiran Dan Pencerahan, 14(1).

Hutajulu, D. (2015). Manajemen Investasi. Manajemen Investasi, 1, 57.

IndoPremier. (2018). Saham dan Mekanisme Terbentuknya Harga. IndoPremier.

Lailiyah, E., Suhadak, S., \& Sulasmiyati, S. (2016). ANALISIS PERBANDINGAN KINERJA REKSADANA SYARIAH DAN REKSADANA KONVENSIONAL (Studi pada Reksadana yang Terdaftar di Otoritas Jasa Keuangan Periode 2012-2016). Jurnal Administrasi Bisnis S1 Universitas Brawijaya, 35(2), 114-121.

Latifah, Anisa. Septiawan, Rizki Gita. Yaksaprawira, Dibyo. Christa, Fanesia. Haliza, Tanzila Nur. Antonio, Olifia Ovista. Larasati, D. A. (2017). Model-model Penilaian Saham yang Populer Dewasa Ini. Kompasiana.

Lestari, W. R. (2020). Kinerja Reksa Dana saham Syariah dan Reksa Dana saham konvensional. Jurnal Magister Manajemen, 01(1), 116-128.

Megasyara, L. H. dan I. (2014). Perkembangan Obligasi Syari'ah (Sukuk) di Indonesia: Sukuk Musyarakah Dan Istishna. Jurnal Akuntansi Unesa, 15.

Nizar, M. (2018). Pendekatan Komprehensif E-Commerce Prespektif Syariah. Perisai: Islamic Banking and Finance Journal, 2(1), 75.

Nuhyatia, I. (2013). Sistem Lembaga Keuangan Shari'Ah. Jurnal Ekonomi Dan Hukum Islam, 3(2), 94-116.

Nurhayati, S. (2017). Peranan Manajemen Keuangan Dalam Suatu Perusahaan. Jbma, IV(1), 85-94.

OJK. (2018). Saham Syariah.

Pajar, R. C., \& Pustikaningsih, A. (2017). PENGARUH MOTIVASI INVESTASI DAN PENGETAHUAN INVESTASI TERHADAP MINAT INVESTASI DI PASAR MODAL PADA MAHASISWA FE UNY. Profita, 1(2), 1-16.

14 | Komparasi Kinerja Instrumen Investasi Berbasis Syariah dengan Konvensional ... 
Prasetyo, Y. (2018). Perbandingan Risiko Dan Return Investasi Pada Indeks Lq 45 Dengan Indeks Jakarta Islamic Index (JII). El-Jizya : Jurnal Ekonomi Islam, 6(2), 287-310.

Putra, B. P. B., \& Mawardi, I. (2016). Perbandingan Kinerja Reksadana Syariah Di Indonesia Menggunakan Metode SHARPE (Studi Kasus Reksadana Syariah Saham, Reksadana Syariah Pendapatan .... Jurnal Ekonomi Syariah Teori Dan ....

Putra, M. (2019). Analisa Kinerja Keuangan Perusahaan Terhadap Return Saham Pada Perusahaan Manufaktur Yang Tedaftar Di ISSI (Indeks Saham Syariah Indonesia). Analisa Kinerjakeuangan Perusahaan Terhadap Return Saham Pada Perusahaan Manufaktur Yang Tedaftar Di ISSI (indeks saham syariah indonesia), 6(1), 1-46.

Ratnawati, V., \& Khairani, N. (2013). Perbandingan Kinerja Reksa Dana Syariah dan Reksa Dana Konvensional. Jurnal Akuntansi (Media Riset Akuntansi \& Keuangan), 1(1), 96113.

Santosa, P. W., \& Huda, N. (2020). Studi efisiensi pasar modal syariah Indonesia: Overreaksi atau momentum? DeReMa: Jurnal Manajemen, 15(2), 140-152.

Setiarsih, A. T. A. (2019). Analisis Perbandingan Kinerja Reksa Dana Campuran Dan Reksa Dana Saham Dengan Menggunakan Metode Indeks Sharpe. Journal of Chemical Information and Modeling, 53(9), 1689-1699.

Sholihin, A. I. (2013). Pedoman Umum Lembaga Keuangan Syariah. Gramedia Pustaka Utama.

Soemitra, A. (2019). Bank dan Lembaga Keuangan Syariah. In Bank dan Lembaga Keuangan Syariah (p. 167).

Sri Sandhi, N. L. P., Panji Sedana, I. B., \& Sri Artini, L. G. (2017). Studi Komparatif Kinerja Portofolio Saham Small Medium Enterprise (SME) di Pasar Modal Indonesia, China, dan India. E-Jurnal Ekonomi Dan Bisnis Universitas Udayana, 3133.

Syafrida, I., Aminah, I., \& Waluyo, B. (2015). PERBANDINGAN KINERJA INSTRUMEN INVESTASI BERBASIS SYARIAH DENGAN KONVENSIONAL PADA PASAR MODAL DI INDONESIA. Al-Iqtishad: Journal of Islamic Economics, 6(2).

Syaifullah, M., Fachrurazi, F., Achmad, F., Usman, S. A., \& Wahyuni, R. (2019). Manajemen Strategi Galeri Investasi Syariah Dalam Meningkatkan Minat Mahasiswa Untuk Berinvestasi Di Pasar Modal Syariah. Al-Mashrafiyah: Jurnal Ekonomi, Keuangan, Dan Perbankan Syariah, 3(2), 108.

Tandelilin, E. 2010. (2010). Dasar-dasar Manajemen Investasi. Keuangan, 34.

Tjiptono, D., \& Fachrudin. (2012). Pasar Modal Di Indonesia. In Salemba Empat.

Yahya, M. (2015). Analisis Normatif Kritis Kebijakan Pemanfatan Obligasi Syariah (Sukuk). Economica, VI(1), 37-56. 
..:: Malia: Jurnal Ekonomi Islam Vol. 12 No. 1, Desember 2020 ::..

16 | Komparasi Kinerja Instrumen Investasi Berbasis Syariah dengan Konvensional ... 